\title{
THE PHENOMENON OF AL-NASKH: A BRIEF OVERVIEW OF THE KEY ISSUES
}

\author{
By: \\ Thameem Ushama
}

\begin{abstract}
The phenomenon of al-naskh discussed over the ages still remains as one of the most outstanding issues in understanding the legal rulings of some of the verses of the Qur'an. This article presents a brief analysis of the meaning of the terms, examines the scopes, explores the benefits, and investigates the conditions for the occurrence of al-naskh followed by a brief highlight of its wisdoms. It also examines its genuine sources. It makes a critical study of the related issues regarding this phenomenon, especially the occurrence of al-naskh in the Qur'an and its kinds as enshrined in the writings of the classical exegetes and jurists. The highlight of the article is the critical exploration of the arguments of two schools of thought where a school stands by its occurrence and the other totally denies it.
\end{abstract}

\section{INTRODUCTION}

From Islamic history of exegesis and jurisprudence it is obvious that many Qur'anic exegetes and jurists have emphasized that the knowledge of al-nāsikh and al-mansükh is extremely important not only to understand the meanings of the Qur'annic verses but also the passages that prescribe legal rulings (ahkām). A brief bibliographical survey reveals that many works on the phenomenon of alnaskh have been authored by scholars such as Qatādah ibn Da'āmah al-Sudūsì (d.117 A.H), Abū 'Ubayd al-Qāsim ibn Sallām (d.223 A.H), Sulaymān ibn Ash'ath Abū Dāwud al- 
Jurnal Fiqh: No. 3 (2006)

Sijistānì (d.275 A.H), Aḥmad ibn Muhammad Abū Ja'far alNaḥhās (d.377 A.H), Ḥibbat Allāh ibn Salamah (d.410 A.H), Abū Bakr Muhammad ibn al-'Arabi (d.543 A.H), 'Abd alRaḥmān ibn al-Jawzì (d.597 A.H), Makkỉ ibn Țālib (d.437 A.H), Badr al-Dīn al-Zarkashì (d.794 A.H), Jalāl al-Dín alSuyutti (d.911 A.H) and their contributions to this science are not only in-depth but also worth nothing. ${ }^{1}$ The scholars assert that God revealed the legal injunctions to reform the people's basic creed ('aqidah), acts of devotion ('ibàdatt) and transactions (mu'àmalāt). However, the basic Islamic creed ('aqidah) i.e. the concept of tawhìd al-ulühiyyah and alrubübiyyah remained unchanged throughout human history. Historically, the message of prophets and messengers was identical with one another. ${ }^{2}$

It is obvious that the 'iba $\bar{a} \bar{a} t$ (acts of devotion) and the mu 'àmalāt (transactions) conform to the 'aqidah's general foundations which are geared to refine the soul and preserve the well being and success of mankind. The Islamic concept of mutual cooperation and fraternity linked them through an indissoluble bond. It is apparent that the

1 Abū Manșūr 'Abd al-Qāhir ibn Zāahir ibn Muhammad al-Baghdādī (1987), Al-Nāsikh wa al-Mansūkh, 'Ammān, Jordon: Dār al-'Aduwī, p. 13-14. Qatādah ibn Da'āmah (died in $118 \mathrm{H}$.) compiled a book AlNāsikh wa al-Mansūkh fi Kitāb Allah Ta'ála. Part of it is available as a manuscript in the library of Dār al-Kutub al-Zāhir under the no: 7899, 'Ulūm al-Qur'ān. A copy of microfilm of this work is available at the academic research center at King 'Abdul 'Aziz University Makkah. Abū 'Ubayd al-Qāsim (died in 224A.H) compiled a book Al-Nāsikh wa al-Mansūkh. A written copy of it is available in the library of Ahmad the third in Istanbul. Abū Dāwud Sulaymān ibn al-Ash'ath al-Sijistāni, the author of Sunan (died in $275 \mathrm{H}$ ) compiled a book on Al-Nāsikh wa al-Mansūkh. 'Abd Allāh ibn al-Ḥusayn ibn al-Qāsim alHasani who lived before 300A.H compiled a book entitled Al-Nāsikh wa al-Mansükh. A microfilm of this book is available at the Academic Research center at Makkah. Abū Ja 'far Muhammad ibn Ahmad ibn Ismā'īl (died in $338 \mathrm{H}$.) compiled a book Al-Nāsikh wa alMansūkh.

2 Al-Qur'ān (21:25). 
issues of an ummah differed from another and a community in a specific period was not similar to another. The methodology of $d a$ ' $w a h$ in the state of development of the ummah was different. Apparently, God-the Lawgiver widened the scope of everything as a sign of mercy from Him in addition to elaborating the imperatives (awāmir) and prohibitions (nawāhy). ${ }^{3}$

Over the years, the phenomenon of al-naskh has been debated. In this respect, there exist two schools of thought. One school strongly advocates the occurrence of al-naskh in the Qur'ân while the other school totally rejects it in the legal sense. In the institutions of higher learning religious scholars and exegetes are divided over the issue. Those who are trained in the traditional Islamic institutions inspire students to believe in its occurrence. Others who are trained in modern educational institutions seem not in favor of the phenomenon of al-naskh and thus influence students and the academic community to reject it. Consequently, there is division and disunity among the scholars and students.

In view of the misunderstandings and confusions, the study presents an analysis of the meaning of the terms al$n \bar{a}$ sikh, al-mansūkh and al-naskh, explores its benefits as expounded by the proponents, examines its sources and studies the conditions for its occurrence. It also explores the rationale for the phenomenon of al-naskh. The most important content of the study is the critical exploration of al-naskh in the Qur'ān. In addition, both the convergent and divergent views are evaluated to know whether or not the phenomenon is true. Last, but not least, conclusion is drawn to guide people to have proper understanding of the issue and its role in interpreting the $a h k \bar{a} m$ in the Qur'ān.

$3 \quad$ Al-Qur'ān ( 21:23). 
Jurnal Fiqh: No. 3 (2006)

\section{MEANING, BENEFITS AND CONDITIONS}

Before everything else it is important to know the meaning of the terms al-nāsikh and al-mansūkh to understand the concept. The terms are derived from the Arabic root word nasakha which literally means to abolish, to replace, to abrogate, to cancel, to invalidate, to remove and to withdraw and thus the lexical meaning of the term al-naskh refers to removal, elimination, abrogation, cancellation or invalidation. ${ }^{4}$ However, the word technically refers to lifting of a hukm (legal ruling) by a legal address. ${ }^{5}$ On the other hand, al-mansūkh lexically refers to "the abrogated" ${ }^{6}$ while its technical meaning refers to the abrogated hukm or the passage of the Qur'ānic revelation. ${ }^{7}$ For example, it has been argued that the verse concerning the law of inheritance has abrogated the hukm on bequest (wașiyyah) by the parents and relatives. ${ }^{8}$ Some jurists and exegetes argue that the Qur'ān in the verse 2:106 endorses this phenomenon of abrogation. As such it is advocated that in the Qur'àn certain temporary legal rulings are being superseded or abrogated by some other permanent and universal rulings, which have been enacted by the same God-the Lawgiver, especially during the course of promulgation of those rulings. Truly, the course of Qur'ānic revelation had been gradual.

It has been argued that the knowledge of al-nassikh and al-mans $\bar{u} k h$ has several benefits and without it, it is not possible to understand the real meanings or rulings of some

4 Milton Cowan, J. (1976), The Hans Wehr Dictionary of Modern Written Arabic, $3^{\text {rd }}$ edition, New York: Spoken Language Services Inc., p. 961. 5 Abū Ișhāa Ibrāhim ibn Mūsa al-Shāṭibì, Al-Muwāfaqāt fi Ușūl alSharì'ah vol. III, p. 107. See also: Amīir 'Abd al-'Azīz (1983), Dirāsāt fi 'Ulūm al-Qur'ān, Beirut: Dār al-Furqān, p. 188.

6 Mannā' al-Qațțān (1983), Mabāḥith fí 'Ulūm al-Qur'ān, Beirut: Mu'assasat al-Risālah, p. 232.

$7 \quad$ Ibid.

$8 \quad$ Ibid. 
of the Qur'ānic passages. As argued by many exegetes the phenomenon of al-naskh contributes to the proper understanding of the laws inherent in the Qur'ān and their applications. It helps to understand the closest meaning of the verses, comprehend the historical development of the legal code in Islamic legal history and the correct explanation of the text.

Besides highlighting the benefits, the exegetes and jurists have also laid down some basic and essential conditions for the occurrence of al-naskh. According to them, the conditions are (1) the abrogated hukm should be on legal rulings; (2) the evidence on the lifting of the hukm should be on a legal message; and (3) the hukm (lifted message) should not be confined to a specific period.

It has been argued that the science of al-naskh is neither unscientific nor speculative although there are some objections to it especially among the rationalists and some other earlier theological schools. According to some exegetes, there are three fundamental sources to know the phenomenon of al-nāsikh and al-mansükh. ${ }^{9}$ They are [1] a clear report from the Prophet or his Companions, [2] ijm $\bar{a}$ ' (consensus) of the ummah on the issues of al-nassikh or almansukh and [3] knowledge on the sequence of the revelation. It is explicit from the discussion that in this regard ijtihâd of a jurist is neither valid nor acceptable. Moreover, individual reasoning by exegetes or jurists or even other means are not accepted, since $a l-n \bar{a} s i k h$, as it is widely understood, was defined and established during the Prophet's time. Hence the 'ulamā' and mujtahidūn can do no more than relying on transmission (riwayah) from the Prophet or the Companions who had witnessed the revelations and were aware of their entire history. ${ }^{10}$

\footnotetext{
Al-Qațāān, Mabāhith, p. 234.

10 Al-'Azīz, Dirāsāt, pp. 197-198.
} 
Jurnal Fiqh: No. 3 (2006)

Therefore, the reliability of the concept in the words of alSuyūtị is nothing but transmission (riwāyah) and history of the revelation. ${ }^{11}$

\section{THE RATIONALE FOR AL-NASKH}

The majority of the 'ulama' argue that this knowledge is vital to jurists, legislators and exegetes so that the legal injunctions are not mixed, confused or falsified. As such, the knowledge of the phenomenon of al-naskh is made a prerequisite for jurists. According to scholars, Traditions (ahādith) urge Muslims to acquire its knowledge. Ibn Salamah (d.410 A.H) states that the starting point of any proper investigation of the Qur'ān is the science of the abrogating and abrogated verses, as related on the authority of the ancient imams; indeed, anyone who engages in the scientific study of the Qur'ân without having mastered the doctrine of abrogation is 'deficient' (naqis $).{ }^{12}$ The textual support for this requirement is generally found in an anecdote told about the fourth Caliph, 'Alì ibn Abū Țālib (d.40 A.H), who expelled a preacher from the mosque in Küfah because he talked about the Qur'ān without familiar with the science of abrogation. One version of this anecdote runs as follows:

It has been related about 'Alí ibn Abū Țālib that one day he entered the Friday Mosque in Küfah, where he saw a man known as 'Abd al-Raḥmān ibn Dabb, a follower of Abū Mūsā al-Ash'arī. The people had gathered around him in order to ask questions, but he was mixing commands with prohibitions, and permissions with restrictions. 'Ali asked him, "Can

11 Jalāl al-Dán al-Suyūṭi (1979), Al-Itqān fí 'Ulūm al-Qur'ān, vol. II, Beirut: Dār al-Fikr, pp. 20-22. See also: 'Abd al-'Ažìm al-Zarqāni (n.d), Manāhil al-'Irfān fí 'Ulūm al-Qur'ān, Cairo: Halabìi, p. 210.

12 Abū al-Qāsim Hibbat Allāh ibn Salamah (1967), Al-Nāsikh wa alMansūkh, $2^{\text {nd }}$ edition, Cairo: Egypt, n.p, p. 4. 
you distinguish between the abrogating and abrogated verses?" He replied, "No". Then 'Ali said, "You destroyed yourself and will destroy others. Who are you the father of?" He said, "I am the father of Yahyā". "Ali said, "You are the father of Yahyā". And he grabbed his ear and twisted it. Then he said, "Do not tell stories in our mosque ever again". ${ }^{13}$

Ibn 'Abbās (d.68 A.H) believed that the verse 2:269 refers to its al-näsikh and al-mansükh, al-muhkam and almutashäbih, al-muqaddam and al-mu'akhkhar and al-harām and al-haläl. ${ }^{14}$ Among the Companions and the Successors who discussed the phenomenon of al-naskh are Ibn 'Abbās, ${ }^{15}$ Ubayy ibn Ka'b, ${ }^{16}$ Al-Hasan al-Basrī, ${ }^{17}$ Al-Daḥhāk ibn Muzāhim, ${ }^{18}$ Qatādah ibn Da'āmah, ${ }^{19}$ Ismā'ìl 'Abd alRaḥmān al-Suddi, ${ }^{20}$ and Muhammad ibn Ka'ab al-Quraẓi. ${ }^{21}$ According to them, the phenomenon of al-naskh exists in the Qur'ān. It is argued by the proponents that the above Companions and the Successors are trustworthy, reliable and accurate and hence their views cannot be ignored.

\section{AL-NASKH IN THE QUR'ĀN AND ITS KINDS}

The phenomenon of al-naskh in the Qur'ān is being discussed at length by several 'ulam $\bar{a}$ ' and scholars to the extent that it has become truly controversial. The scholars

3 Ibid., p. 5.

14 This is recorded by Ibn Jarir.

15 'Abd al-Raḥmān ibn al-Jawzìi (n.d), Nawāsikh al-Qur'ān, Beirut: Dār alKutub al-'Ilmiyyah, p. 18.

16 Ibid.

17 Ibid.

18 Muhammad ibn Jarīr al-Ṭabari (1997), Jāmi al-Bayn fi Tafsīr al-Qur'ān, vol. I, Beirut: Dār al-Kutub al-'Ilmiyyah, p. 51.

19 Ibid.

20 Ibid.

21 Ibid. 
Jurnal Fiqh: No. 3 (2006)

have classified it into three kinds and the first is abrogation of the verse and the hukm together. It implies that both the rulings and the wordings of an earlier revelation had been abrogated and were not replaced. ${ }^{22}$ Neither the rulings nor the wordings of the abrogated text have the relevance. In this case, the wordings of an earlier revelation are not included in the Qur'ān. This view is substantiated by a hadith recorded by Muslim on the authority of ' $\overline{\mathrm{A}}$ 'ishah that it has been revealed in the Qur'ān, that ten clear suckling make the marriage unlawful. Then it was abrogated and substituted by five suckling. ${ }^{23}$ It is obvious that the verse on ten suckling is neither recited nor found in the muṣhaf of 'Uthmān. This kind of abrogation of both the hukm and the text is evidenced by a hadith. ${ }^{24}$

Second, abrogation of the text leaving the hukm implies that a Qur'ānic revelation has been omitted, i.e. it had not been replaced in the muṣaf. ${ }^{25}$ However, the legal ruling prescribed by the abrogated or omitted revelation is still in use. The following quotation illustrates this point: 'Abd Allāh ibn 'Abbās reported that 'Umar ibn al-Khațāāb sat on the pulpit of Allah's Prophet and said: Allah sent the Prophet with truth and He sent down to him. We recited it, retained it in our memory and understood it. Allah's Prophet awarded the punishment of stoning to death (to

22 Muhammad 'Alī al-Ḥasan (1983), Al-Manār fī 'Ulūm al-Qur'ān, 'Ammān: Dār al-Arqam, p. 53. See also: Ibn Salamah (1966), Al-Nāsikh wa al-Mansūkh, Cairo: n.p, p. 5.

23 Sahịih Muslim, vol . III, Hadith No. 3421.

24 Aḥmad ibn Muhammad Ṭāhūn (1980), Ma 'al-Qur'ān al-Karīm, vol. II, Saudi Arabia: Mațābi‘ Ahrām al-Jīrāt al-Kubrā, p. 22.

It is narrated on the authority of 'Abd Allāh ibn Mas'ūd who said: "The Prophet recited to me a verse. I committed it to memory and recorded in my muṣhaf. At night I went to my bed and did not refer to itfurther. I opened my muṣhaf the next morning and found white empty paper andimmediately informed the Prophet. He said, 'O Ibn Mas'ūd! That verse has been lifted by Godlast night.

25 Hasan, Al-Manār., p. 31. See also: Al-Suyūțī, Al-Itqān., p. 22. 
the married adulterer and adulteress) and after him; we also awarded the punishment of stoning. I am afraid that with the lapse of time, the people (may forget it) and may say, 'we do not find the punishment of stoning in the Book of Allah,' and thus go astray by abandoning this duty prescribed by Allah. Stoning is a duty laid down in Allah's Book for married men and women who commit adultery when proof is established, or if there is pregnancy or a confession. ${ }^{26}$ The Sunnah has maintained this punishment of stoning to death for adultery by married people, while the text prescribing this punishment is not included in the Qur'ān.

Third, abrogation of the $h u k m$ without the text ${ }^{27}$ implies that both the legal rulings and wordings of an earlier revelation had been replaced by another revelation, because the earlier rulings had actually been abrogated or cancelled. In this case, the wordings of the revelation of the abrogated hukm are included in the Qur'ān as found in the verses 33:50 and 33:52. These verses are one among a few clear examples of the abrogation of hukm even though it referred to the Prophet. For Muslims in general, the number of wives has been confined to four only. The legal ruling on 'iddah is another example of the abrogation of the hukm without the text. Many books have been compiled on this kind of abrogation, and many verses have been quoted.

According to scholars who are in favour of the phenomenon of al-naskh, it is divided into four kinds. They are firstly, abrogation of the Qur'ān by the Qur'ān. ${ }^{28}$ This is considered permissible. In this regard, it is stated that the verse on 'iddah for one year had been abrogated by another

26 Al-Bukhārī, vol VIII, Ḥadīth No. 81. See also: Muslim, vol. III, Hadīth No. 4194.

27 Al-Qațān, Mabāhith, p. 238. See also: Jamāl al-Dīn Abu al-Faraj 'Abd al-Raḥmān al-Jawzì (1984), Nawāsikh al-Qur'ān, First Edition, p. 114.

28 Al-Qaț̣ān, Mabāhith, p. 236. 
Jurnal Fiqh: No. 3 (2006)

verse which establishes iddah for four months and ten days. The second kind is abrogation of the Qur'ān by Sunnah. ${ }^{29}$ This is further classified into two kinds: abrogation of the Qur'ān by solitary Sunnah. The majority of the scholars is not in favor of it, for the Qur'ān was transmitted by tawātur whereas solitary report of a Sunnah is suspicious. Hence, it is not permissible and not lawful to lift the strong by the suspicious. The other is abrogation of the Qur'ān by Sunnah mutawātir (successive transmission). This has been permitted by famous jurists such as Imām Mālik, Abū Hanifah, Ahmad ibn Hanbal, and Mu'tazilites and some other theologians, because both the Qur'ān and Sunnah are wahy (revelation) from God. ${ }^{30}$ They quote the verses 53:3-4 and 16:44 to substantiate their arguments.

However, al-Shāfi ‘í, ahl al-Ẓāhir and Aḥmad ibn Hanbal in another narration prohibit this kind of abrogation of the Qur'ān by Sunnah mutawātir. ${ }^{31}$ They quote the verse 2:106 to support their argument. According to them, Sunnah is neither superior to the Qur'ān nor even similar. As an example of abrogation of the Qur'ann by Sunnah, the verse $2: 180$ is quoted. It is understood from the text of 2:180 that there is permission for wașiyyah for the parents and relatives. But according to some exegetes the Sunnah abrogated it. ${ }^{32}$ Some had objected to this kind of abrogation of the verse by Sunnah in light of the evidence that the Sunnah is $\bar{a} h \bar{a} d$.

The third kind is abrogation of the Sunnah by the Qur'ān which is permitted by several exegetes. ${ }^{33}$ For

29 Ibid.

$30 \quad$ Ibid., p. 237.

31 For details see Kitāb al-Risālah, (Cairo, n.d.), pp. 30-73. English translation by M. Khadduri, op.cit., pp. 123-45. For a brief summary of al-Shāfi'‘ ${ }^{\prime}$ views, see also: Seeman, K. (1961), al-Shāfi' ${ }^{i}$, al-Risālah, Lahore: n.p, pp. 53-85. See also: Imām Aḥmad, Rawİah al-Nādhir, p. 55.

32 The Prophet said: "Indeed, Allah gives everyone his due share and there is no wasiyyah for the heir.

33 Al-Qațāan, Mabāhith, p. 237. 
instance, Sunnah confirmed the prayer direction towards Bayt al-Maqdis for which there is no verse in the Qur'ān. This is abrogated by the Qur'ān in the verse 2:144. ${ }^{34}$ The observation of fast on the day 'A shurah was confirmed by Sunnah and the Qur'ān abrogated it by the verse $2: 185 .^{35} \mathrm{It}$ has been argued that eating, drinking and sexual intercourse were prohibited by Sunnah during the nights of Ramaİan for those who observed fast. Then, it was abrogated by the verse $2: 187 .^{36}$

It is even argued that the Prophet felt annoyed with the people of Makkah in the year of Hudaybiyah when the treaty was signed, one of those conditions was to return any newly converted Muslims who had escaped to Madinah from Makkah. After the treaty, Abū Jandal and a group of Makkans became Muslims and came to Madinah. They were returned to Makkah according to the terms of the treaty. Then a woman came and declared her Islam. The Prophet and the Muslims planned to send her back to the Quraysh in Makkah based on the conditions of the treaty, but was not sent as God commanded in the verse 60:10. ${ }^{37}$ These are some of the examples of abrogation of the Sunnah by the Qur'àn.

Fourthly, scholars argue that there is abrogation of Sunnah by another Sunnah ${ }^{38}$ which is sub-divided into four kinds: abrogation of sunnah mutawatir by another sunnah mutawātir; abrogation of sunnah āhād (solitary) by another sunnah āhād; abrogation of sunnah āhād by sunnah mutawātir; and abrogation of sunnah mutawätir by sunnah $\bar{a} h \bar{a} d$. It is stated that the first three categories are 
Jurnal Fiqh: No. 3 (2006)

permissible, and as for the fourth; there are differences among scholars. Their views on this issue are similar to that of abrogation of the Qur'ān by solitary Sunnah. In other words, scholars did not favour it.

\section{AL-NASKH: ITS OCCURRENCE AND WISDOM}

According to the proponents of the phenomenon of alnaskh it had occurred only in Madinah and it was rare in the Makkan revelation. The rationale for it was that the Makkan revelation had communicated only the major issues of rules and regulations and in particular was more concerned about key concepts, such as 'aqidah, its pillars, principles and problems, and followed by moral dimensions $(a k h l \bar{a} q)$. The Muslims and the Apostle migrated to Madinah where the general laws of Islam and its principles of 'aqidah (creed) and akhlāq (morality) were revealed elaborating the fundamental rules for the establishment of Islamic socio-political and economic order. Such issues treated by the Qur'ān in the Makkan phase did not contain al-naskh except those that are related to the sub divisional jurisprudence. When the Muslims migrated to Madinah, their centre was shifted along with them. The Qur'annic revelation continued which comprised the specimen of legislation in numerous areas relating to individual, social and collective life. The laws relating to governing, social and financial matters, issues of war and fighting, relationship with non-Muslims, polytheists and people of the Scripture were revealed during this period. Each of the above issue was the major content of the Madinan revelation. Needless to say, the Makkan revelation seldom contains these issues. Therefore, the question of al-naskh did not arise concerning the cancellation of the previous legal rulings in the Makkan revelation. Al-Shātibi states that alnaskh had occurred mainly in Madinah, since it was a necessity of divine wisdom to facilitate and ease the legal 
rulings. ${ }^{39}$ It was in Madinah that the legal rulings were fully revealed. Al-Shātibi further states that the legal rulings revealed in Makkah were incomplete and hence, al-naskh in Makkan phase was very little.

Al-Qatțān has furnished four reasons for abrogation in the Qur'ān. ${ }^{40}$ They are (1) considering the welfare of the servants of God, (2) development of laws in an organized manner for the establishment of $d a$ 'wah and the evolution of the status of the people, (3) as trials and tribulations from God and His test for Man's obedience, and (4) consent and nihilism and finally goodwill for the ummah and its facilitation because when al-naskh is burdensome, then its reward will be handsome. It is said that there is consensus among scholars and jurists that al-naskh had occurred in those verses which are related to the commandments (awämir) and the prohibitions (nawähy). ${ }^{41} \mathrm{Al}$-Naskh did not occur on the subjective information such as threats and promises as it is found in the narrative of the ancient nations. Mujāhid ibn Jabr (d.104 A.H), Sa'id ibn Jubayr (d.95 A.H), 'Ikrimah ibn 'Abd Allāh (d.107 A.H), AlDaḥ̣āk ibn Muzāahim and Ibn 'Umar have stated that alnaskh did not occur except on the commandments and the prohibitions. ${ }^{42}$

\section{AL-NASKH BY SUBSTITUTION AND NON- SUBSTITUTION}

According to Muslim jurists, the abrogated hukm was either substituted (by another hukm) or not. The substitution in its place by another ruling is known as al-naskh bi-badl (abrogation by substitution) and non-substitution by

9 Al-Shāțibī, Al-Muwāafaqāt fi Ușūl al-Tafsìr, Vol. III, p. 104.

Al-Qattān, Mabāhith., p. 240.

41 Muhammad Āābiä (1983), Bahth Jadìd 'an al-Qur'ān al-Karìm, Cairo: Dār al-Shurūq, p. 174.

42 Al-Suyūṭi, Al-Itqān. 
Jurnal Fiqh: No. 3 (2006)

another hukm is known as al-naskh bi-ghayri badl (abrogation without substitution). It is argued by scholars that both are rationally permissible and such things occurred in the Islamic tradition according to the $i j m \bar{a}$ ' of the scholars. ${ }^{43}$

The example of abrogation by substitution is that God prohibited Muslims from fighting the infidels in the beginning of Islamic mission and preferred them to forgive and forget them. ${ }^{44}$ Then, God abrogated this prohibition and permitted them with jih $\bar{a} d .{ }^{45}$ In the verse 22:41, God says that if the Believers are given a way to establish them in the land, they will establish regular prayer and give regular charity, enjoin the right and forbid wrong. Then, God ordered the Muslims to drive the infidels out and should the Muslims disobey this command they will be severely punished as stated in the verses 9:39-40.

The example of abrogation without substitution is that God commanded the offering of charity before any secret consultations with the Prophet. ${ }^{46}$ Then, He lifted this injunction from the people without commanding them for something else in its place. This implies that He left them in free condition without directing another hukm. ${ }^{47}$ This is the view of the majority of the 'ulama'. However, some $\mathrm{Mu}$ 'tazilites and Zahirites disagree with this view. According to them, it is not legally permissible and they quote the verse of the Qur'ān to strengthen their view. ${ }^{48}$ The reason for their doubt, according to some observation, is that the verse explicitly indicates that it is necessary to bring in the abrogated place of hukm another hukm that is either similar or better.

\footnotetext{
43 Al-Zarqāni, Manāhil, p. 220.

44 Al-Qur'ān (2:109).

45 Ibid., (22:39-40).

46 Al-Qur'ān (58:12).

47 Ibid., (58:13).

48 Ibid., (2:106).
} 
According to some scholars, abrogation of the hukm by substitution is divided into three kinds. The first kind is abrogation of a tough ruling by an easier substitute. For example, prohibition of eating, drinking and sexual intercourse after the sleep at night during the month of Ramaİan was substituted by another hukm that allowed these actions. ${ }^{49}$ An example of the second kind is abrogation of a hukm by similar substitute i.e. God first made people to face Bayt al-Maqdis in their prayer. ${ }^{50}$ Then, He substituted it by similar ruling whereby He made people to face $\mathrm{Ka}$ ' $b a h$ as the qiblah in their prayer. ${ }^{51}$ As far as these two kinds are concerned there is no disagreement among the 'ulam $\bar{a}^{\prime}$ in permitting them rationally and their occurrence legally. However, there are differences of views regarding abrogation of early $h u k m$ by heavier substitute. The majority of the ' $u$ lam $\bar{a}$ ' argues that it is also rationally permissible just like the two previous cases. They substantiated their views with some examples to confirm such an occurrence by heavier substitute. ${ }^{52}$

Some examples are mentioned to prove their argument about abrogation of lighter ruling by heavier one. They are [1] God abrogated the permissibility of wine by its prohibition, [2] Hadd (capital punishment) for adultery practiced at the dawn of Islam confining to the house was abrogated by flogging, banishing with respect to virgin and stoning in public with respect to the matured, and [3] obligation upon the Muslims at first to fast on the day of 'Ashura was then abrogated by obligatory fast in the whole of RamaĪan with an option between fast and ransom, and then without an option by fixing fast on the residents as compulsory.

Ibid., p. 222. Al-Qur'ān (2:187).

Ibid.

1 Al-Qur'ān (2:144).

52 Ibid. 
Jurnal Fiqh: No. 3 (2006)

\section{CONVERGENT VIEWS}

As familiarity with the science of abrogation is considered necessary for proper understanding of certain verses of the Qur'ān, many views are presented on it. Some 'ulama' accepted its occurrence while others totally rejected. The history shows that the ulam $\bar{a}^{\prime}$ have different views about the total number of abrogated verses. The verse 9:5 (âyat alsayf) was said to have abrogated one hundred and thirteen verses which contain teachings to have patience and perseverance, forgiveness and tolerance in adversity and hardships. ${ }^{53}$ Ibn Hazm (d.320A.H) argues as 214 verses as abrogated, ${ }^{54}$ Abū Ja'far al-Nahhās (d.377 A.H) as $134,{ }^{55}$ Ibn Salamah (d.410 A.H) as $213,{ }^{56}$ Al-Baghdādi (d.429 A.H) as 134, ${ }^{57}$ Ibn Barakāt (d.520 A.H) as 210, ${ }^{58}$ Ibn 'Arabi (d.543 A.H) as $21,{ }^{59} \mathrm{Ibn}$ al-Jawzi (d.597 A.H) as $246^{60}$ and AlSuyūtị (d.911 A.H) as 21. ${ }^{61}$ According to Shāh Waliullah (d.1763 C.E) the number of abrogated verse is only five. ${ }^{62}$ He seems to have reached this conclusion after harmonizing the passages which were deemed contradictory.

Al-Shahrastān $\bar{i}$ has discussed this issue and substantiated it on rational grounds. According to him Islam abrogates all previous codes or scriptures. He takes

53 Ibn Khuzaymah (1323A.H), Al-Mujāz fi al-Nāsikh wa al-Mansūkh, Cairo: n.p., p. 265.

54 Aḥmad Hijāzī al-Saqā (1978), Lā Naskha fí al-Qur'ān, Cairo: Dār alFikr al-'Arabi, p. 232.

55 Ibid.

56 Ibid.

57 Ibid.

58 Ibid.

59 Ibid.

60 Ibn al-Jawzì, Nawāsikh al-Qur'ān, pp. 23-24.

61 Al-Suyūțî, Al-Itqān, vol. I, p. 23.

62 Shāh Waliullāh al-Dehlawī (1988), Al-Fawz al-Kabìr fi Ușūl al-Tafsìr, Beirut: Dār al-Bashā'ir al-Islāmiyyah, pp. 96 and 78-96. 
the doctrine of abrogation in a broader sense and emphasizes the abrogation of previous codes by Islam. He argues that abrogation is not an innovation but is a continuous process of change of law which culminated in Islam. He raises a question if contemporary law is subject to constant alteration to meet changing conditions why is it impossible that laws given to one time should be abrogated elsewhere at another time? According to him the law corresponds to action and the active changes of death and life, man's creation and annihilation, sometimes gradually, sometimes instantaneously correspond to the legal changes of the lawful and the prohibited. God orders men's action as He pleases and must not be asked what He is doing. According to him that if we consider the formation of man from his full stature we see that each progressive form abrogated its predecessor. Similarly man progressed from code to code till the perfection of all codes was reached. Nothing lies beyond it but the resurrection. ${ }^{63}$ However it is not clear whether he advocates the concept of abrogation of the individual verses. From the argument, it is possible to infer that he justified abrogation in the Qur'ān based on his conviction that the previous codes were abrogated by Islam.

Al-Shāfi' $\bar{i}$ has discussed the phenomenon of al-naskh in detail in al-Risālah. He argues that the Qur'ānic injunctions can be abrogated only by the Qur'ān and the Sunnah by the Sunnah. He disagrees with the views that Sunnah can abrogate the Qur'ān and vice versa. He also argues that the Prophet was ordered to follow the revelation and not to change the Qur'ân itself. He quotes many passages which obviously indicate that God alone can change the revelation. ${ }^{64}$

63 Al-Shahrastāni, Kitāb al-Nihāyāt al-Iqdām fi 'Ilm al-Kalām, Ed. and trans. by Guillaum (1934), Oxford, pp. 158-159. Quoted in Donaldson. Dwight, M. (1953), Studies in Muslim Ethics, London, p. 52.

64 Al-Shafi'i ${ }^{\prime}$ (1321A.H), Al-Risālah, Cairo: n.p., p. 17. 
Jurnal Fiqh: No. 3 (2006)

Ibn Kathir (d.774 A.H) argues that those who followed the Jews on the phenomenon of al-naskh are in the state of kufr (unbelief).$^{65}$ He states that God revealed the laws in accordance with His wish in the context of the earlier ummah. The Jews denied al-naskh in spite of its occurrence even in the earlier scriptures and the laws of the past; such as God made lawful to Adam the marriage between his daughters and sons, and then He prohibited it. Likewise, Prophet Nūh was permitted to consume the meat of all animals after his exit from the ship, and later on, some provisions were cancelled. The marriage of two sisters at a time was permissible to Isrá'íl and his progeny, and it was later on prohibited in the shari 'ah of Tawrät and others.

Al-Naskh in the sense of intra-scriptural abrogation was, of course, as mentioned in the foregoing pages was rejected by the Jews on the grounds that the ideas of abrogation of divine law implies the recognition of bada'(knowing something later after being ignorant of it). Muslims were clearly sensitive to these implications. It may lay behind the contention of some Muslims that there are no abrogative or abrogated verses in the Qur'ān and sought to counter it by drawing a distinction between naskh and bada'. Al-Naḥhās includes a discussion of the difference between these two terms in his treatise on abrogation, something that, to the best of his knowledge, had never been mentioned before in a naskh treatise. ${ }^{66}$

According to al-Naḥhās, al-naskh refers to something that has previously been permitted but has now become forbidden or vice-versa due to God's desire to improve the situation of His slaves. ${ }^{67} \mathrm{Al}-\mathrm{Naskh}$, then, does not involve any change in the divine Will, rather God's recognition of the facts that the situation of the human being would

65 Ibid.

66 Abū Ja'far al-Naḥhās (1938), Al-Nāsikh wa al-Mansūkh, Cairo: n.p, p. 4.

67 Ibid., p. 9. 
change over time. God knew, at the outset, what these changes would be, and He knew it would eventually become necessary to abrogate the original command or prohibition. As an example of this, al-Naḥhās quotes the change in the direction of prayer, from Jerusalem to Makkah; and God's permission for the Muslims to work on the Sabbath, though it had been totally prohibited for the Jews to work on the very day.

Bada' which has been accepted by Shi'ites too, on the other hand, refers to the abandonment of something that had been firmly resolved upon, as for example when one says, "Go to so-and so," But later you say," Don't go to him", or when you say, "Plant such-and-such in this year," but then you say," Don't do that." These, according to alNaḥhās, is bada'; naskh on the other hand, refers to the abrogation of some command or prohibition that God had meant to apply only during the lifetime of a certain period of time, knowing from the outset that this hukm will remain in force until such and such time, and later when circumstances change, a new hukm will be enforced. ${ }^{68}$

As stated above, validity of the phenomenon of al-naskh has been debated by classical exegetes and jurists. As in the past, contemporary Qur'ān scholars also discuss this issue at length. Sayyid Qutb (d.1966 C.E) has discussed the issue in his exegesis Fí Zilāl al-Qur'ān. He is harshly criticized by modern scholars who are the strong proponents of the concept of al-naskh, for completely denying it. ${ }^{69}$ The present study discovered that it is not correct to conclude that Quṭb totally denies the phenomenon of al-naskh, but he does not agree with the commonly held view on al-naskh of the àyah on 'iddah. He argues that there is no abrogation in

68 Ibid., p. 10.

69 Șalāḥ 'Abd al-Fattāḥ al-Khālidī (1986), Al-Manhaj al-Harakỉ fi Zilāl alQur'ān, Jeddah: Dār al-Manārah, pp. 349-354 
Jurnal Fiqh: No. 3 (2006)

this case, for each a $y a h$ presents a different aspect of the issue. He asserts that the verse 2: 240 provides a right for a widow to remain in the home of husband for one year by his bequeath, whereas the verse 2: 234 makes it obligatory for a widow to stay 4 months and 10 days. According to Qutb, these verses are addressing two different situations and therefore no abrogation is required..$^{70}$

Due to this view, some exegetes and scholars have criticized Sayyid Quṭb. In fact discussions in Fi Zilàl show that he was not against al-naskh. He neither holds a view that a major part of the Qur'ān is abrogated nor favours the idea of total rejection of abrogation. He is moderate and does accept the phenomenon of al-naskh, but not in the way the majority did. The analysis of Fi Zila $l$ leads to confirm that Qutb allows al-naskh of the Qur'àn by the Qur'ān and by the hadith. However, he uses different terms ta 'dil (alteration), taghyir (change) and raf' (lifting) to imply al-naskh of a ruling by a different one. ${ }^{71}$ But it is true that Qutb disagrees with some of the commonly held views of some of the verses of the Qur'ān as abrogated. ${ }^{72}$

Tabatabai (d.1983 C.E) argues that the common notion of abrogation, that is, a canceling of one law or code by another, is based on the idea that a new law is needed because of a mistake or shortcoming in the previous one. It is clearly inappropriate to ascribe a mistake in law making to God. He further argues that in the Qur'ann, the abrogating verses mark the end of the validity of the abrogated verses because their need and effect was of a temporary or limited in nature. In time the new law appears and announces the end of the validity of the earlier law. Considering that the Qur'àn was reveled over

70 Sayyid Quțb, Fì Zilāal al-Qur'ān, vol. 1, p. 259.

71 Ibid., vol. 1, p. 102, Analysis of the footnote of the verse 2: 106 reveals that Qutb has believed in the concept of naskh in the Qur'ān.

72 Sayyid Quṭb, Fì Ziläl al-Qur'ān, vol. 1, p. 259. 
the period of twenty three years in ever changing circumstances, it is not difficult to imagine the necessity of such laws and it is in this light that the wisdom of abrogation within the Qur'ān should be regarded. ${ }^{73}$

\section{DIVERGENT VIEWS}

In spite of the majority of the 'ulama' support the occurrence of al-naskh in the Qur'ān, some 'ulama' totally disagree to this phenomenon. What is interesting is that those who hold divergent views on al-naskh also quote the Qur'ānic passages as the basis of their argument. The proponents of al-naskh quote the verses 2:106 and 16:101 to substantiate their argument. But according to some 'ulama', the word $\bar{a} y \bar{a} t$ mentioned in the above verses refer not to the text of the Qur'ān but to the previous Scriptures inclusive of Torah and Bible. ${ }^{74}$ Consequently, an interpretation of this type would of course render the $\bar{a} y \bar{a} t$ under discussion irrelevant to the occurrence of al-naskh in the Qur'ān.

It has been argued by those who do not advocate abrogation that the classical theory of al-naskh does not originate from the Prophet for there is no authentic report from him as to the existence of the abrogated verses in the Qur'an in the sense that the scholars understand it. According to them, had any passage of the Qur'ān been actually abrogated the Prophet would have definitely pointed out. They also argue that as the teachings of the Qur'ān are valid for all ages, it is inconceivable that the Prophet had left such an important issue to the discretion of the Companions or later generations. This view is

73 Sayyid M.H. Tabatabai (1987), The Qur'ān in Islam, Its Impact on the Life of Muslims, London: Zahra Publications, p. 45.

74 Mohammad Hashim Kamali (2000), Principles of Islamic Jurisprudence, $2^{\text {nd }}$ revised edition, Kuala Lumpur: Ilmiah Publishers, p. 163. 
Jurnal Fiqh: No. 3 (2006)

further substantiated that the Companions themselves are reported to have differed among themselves with regard to the abrogation of certain verses in the Qur'ān.

As a proof of their argument against abrogation, they quote the report by Ibn 'Umar whereby he stated that the verse 2:184 has been abrogated by 2:185; but Ibn 'Abbās argued that the verse 2:184 is for the aged persons. Ibn 'Abbās also suggested that they may feed a poor man every day in lieu of each fast. In this context, it is reported that Anas ibn Mālik used to feed the indigent in his old days during RamaĪan and did not keep fast. ${ }^{75}$ He did this on the basis of Ibn 'Abbās interpretation. According to those who disagree with the phenomenon, this is not the only occasion that the Companions have differed but there are a number of other occasions where they differed. This sort of difference in understanding the legal rulings is quoted as an argument that the Companions have not received any formal instruction from the Prophet.

It has been argued that the Jews denied the existence of al-naskh in the revealed scripture. The reason for their denial was that they were jealous of Muslims due to change of direction of the qiblah from Bayt al-Maqdis to Ka'bah. They discredited Islam by their denial and spread rumors that the Prophet commanded his Companions to do certain things and then prohibited them from that later on.

Although 'Abduh (d.1905 C.E) accepted the phenomenon of al-naskh in principle, he too has denied it in the verses of the Qur'àn. ${ }^{76}$ He seems to harmonize the verses that are apparently conflicting. Sayyid Aḥmad Khān rejects the phenomenon of al-naskh. According to him, the word naskh in 2:106 refers to abrogation of the previous

Sahịị al-Bukhārī, vol. III, Hadīth No 202, Leiden., n.d.

76 Muhammad 'Abduh (1954), Tafsìr al-Manār, vol. II, Cairo: n.p., p. 1380 
codes revealed to the prophets of the past. ${ }^{77}$ Muhammad alKhulāri harmonizes all the verses believed to be abrogated by al-Suy ūtî. ${ }^{78}$ In addition, the famous scholars who denied al-naskh, are Abū Muslim al-Isfahānī (d.322 A.H), 'Abd alȘamad Raḥmānī, Maḥmūd Mușțafā Baḍāwī, Muhammad 'Alì Hasan al-Mohāní, Muhammad Rahmmatullāh al-Hindí, 'Abd al-Raḥmān al-Jazā' $\bar{i}$ Rashỉd Riḍā, Shaykh Muhammad al-Ghazālì, Muhammad Asad, 'Abd al-Hamīd Abū Sulaymān and a few others.

Among those who criticized the phenomenon of al$n a s k h$ in the classical period was Abū Muslim al-Isfahāni, a well-known rationalist of the $M u$ 'tazilah School. He rationally accepted it but prohibited its occurrence in the legal sense. ${ }^{79}$ He substantiates his proposition by quoting the verse 41:42 and interprets that the verse implies that the legal rulings of the Qur'an can never be false. He, therefore, renames al-naskh as al-takhsis (qualifying or specifying).$^{80}$ However, scholars of the sciences of the Qur'ān disagree with Abu Muslim al-Isfahāni's views and distinguish alnaskh from al-takhșis. According to them these are referring to two different things.

Al-Isfahāni argues that all instances of the so-called abrogation in the Qur'ān are in fact no more than takhșiș (qualifying or specifying) of one text by another. ${ }^{81}$ According to him, the word $\bar{a} y \bar{a} t$ in this passage means not a portion of the Qur'ānic text, but miracle. The word àyah

77 Sayyid Ahmad Khan (n.d.), Tafsir al-Qur'ān, Lahore: n.p, pp. 137-140.

78 Muhammad al-Khulàri (1938), Ușūl al-Figh, Cairo: n.p., pp. 246-251.

79 Muḥammad ibn 'Umar Fakhr al-Dìn al-Rāzi (1997), Mafâtīh al-Ghayb, vol. I, Beirut: Dār Ihyāa al-Turāth al-'Arabì, p. 444. See also al-'Āmidi, 111: 165.

$80 \quad$ Ibid.

81 Ṣubḥi Sạliḥ (1983), Mabāhith fi- 'Ulūm al-Qur'ān, 15 th edition, Beirut: Dār al-'ilm li al, Māliyin, p. 274 (Taken from Hashim Kamali's book). 
Jurnal Fiqh: No. 3 (2006)

used in the verse 16: 101 too means miracle. For after all ayyh literally means sign and miracle is a sign. According to him, takhșis means that one revelation explains, in more detail or according to specific circumstances how another revelation should be understood..$^{82}$

Al-Isfahāni's view is mainly based on his understanding of the verse 41:42. What al-Isfahāni $\bar{i}$ argues is that the verses that are rendered as abrogated were, in fact, revealed for a specific period of time, mainly in the Makkan phase that was addressed to the Muslim community at that time and at that stage of socio-political development. ${ }^{83}$ Once this stage was over and the Muslim society entered a new phase in Madinah, according to him different rulings were revealed. To him, it was not revealed to invalidate or abrogate the previous rulings but to address a different society, which was in a different stage and facing with different issues and problems.

However, his interpretation of the above verse is rejected by many. Al-Naskh, as understood in the Qur'ānic context, is not equivalent to $i b t a \bar{l} l$ and the message in the ayah is that; there was no revelation before the Qur'ān which could invalidate it. The interpretation of al-Qurțubi seems to be meaningful, because it is supported by history. As there was no revelation before, which could falsify the Qur'ān, the revelations to Moses and Jesus have not done this. And, since there will not be another revelation after the Qur'ān, as there will not be another prophet after Prophet Muhammad who could receive the revelations, thus, the Qur'ân can never be invalidated.

While the classical scholars' views are based on linguistic and juristic consideration, the modern scholars have adopted a different approach to the issue. They have

82 Ibid.

83 Abū Zahrah, p. 155. 
based their arguments on the historical facts and other factors that led to the development of the controversy. Modern Muslim scholars' approach to the phenomenon is entirely different from the approaches of the past. It is different, in the sense that the modern scholars' approach and methodology are shaped by the problems and realities of the contemporary world. They tend to approach every issue by analyzing it in the context of the social paradigm. In his book The Crisis of the Muslim Mind, Abdul Hamid Abu Sulayman ${ }^{84}$ has rejected the occurrence of al-naskh in the Qur'ān. To quote him:

The concept of al-naskh as traditionally elaborated, reflects a static understanding in the methodology of Islamic thought, for it acts without taking notice of the difference between the general and universalistic nature of the Qur'annic teachings as opposed to the specific and particularized treatment of subjects found in the Sunnah. The traditionalist concept of al-naskh also reflects a total lack of appreciation for the elements of time and place in the process of interpreting and applying texts, as well as in comprising and analyzing them. ${ }^{85}$

In brief, what Abdul Hamid is trying to say is that, during the twenty-three years of the lifetime of the Prophet and the coming of revelation, the Muslim society had gone through different stages of comprehensive change, facing new challenges and realities. The revelation at that time carried the Muslims through all these eras and stages of

84 Abdul Hamid Abu Sulayman is a contemporary Muslim thinker who is committed to Islamization of knowledge. He was a former director of International Institute of Islamic Thought, U.S.A., and rector of International Islamic University Malaysia. He published a number of works on contemporary Islamic thought.

85 Abdul Hamid Abu Sulayman (1994), Crisis in the Muslim Mind, $2^{\text {nd }}$ Edition, Herndon, Virginia, USA: The International Institute of Islamic Thought, p. 49. 
Jurnal Fiqh: No. 3 (2006)

comprehensive change. Now, the Qur'ān is carrying the Muslims through all these eras and the Qur'ann dealt with people as an individual and a community, and led them from individual and minority status to the level of society and government, and humiliation, persecution and weakness to dignity and power. ${ }^{86}$

Abdul Hamid in dealing with this issue is greatly concerned with Muslim non-Muslim relations, as the title of his book The Islamic Theory of International Relations: New Dimensions for Islamic Methodology and Thought signifies. He is trying to validate the verses, which encourage a friendly relation with non-Muslims, which are considered as abrogated by the majority of the 'ulama's'. He claims that the classical understanding of the issue has brought negative implications as far as Muslim and non-Muslim relations are concerned. ${ }^{87}$ As an example of the negative effects of the understanding of al-naskh by many he quotes the 'verse of the sword' (ayat al-sayf). ${ }^{88}$ Abdul Hamid argues that this verse was revealed when the Muslims were under constant attack and subjugation by the non-Muslim forces. This helped the Muslim jurists to give moral support before the death community to fight the big powers of the earth before the death of the Prophet. These approaches, as Abdul Hamid argues, have the advantage of a direct and simple explanation. It added, according to him, tremendous moral power to the war efforts against the stubborn, imperial Roman enemy of the north. ${ }^{89}$

Abdul Hamid is convinced that the phenomenon has been misinterpreted and misconceived. According to him, if

$86 \quad$ Ibid., pp. 49-50.

87 Abdul Hamid Abu Sulayman (1993), Towards an Islamic Theory of International Relations. New Directions for Methodology and Thought, $2^{\text {nd }}$ Revised Edition, Hendon, Virginia: The IIIT, p. 44.

88 Al-Qur'ān (9:5).

89 Abū Sulaymān, Crisis, pp. 49-52. See also: Abū Sulaymān, The Islamic Theory, p. 44. 
this misconception is removed, then the misinterpretation and application of abrogation can be corrected. In this way, according to him, the damaging effects of the methods of abrogation would be eliminated. Abdul Hamid argues that it is important to put the concept of abrogation back into its proper context so as to limit it basically to abrogation of the messages and $\bar{a} y \bar{a} t$ revealed before the message of Islam was complete. According to him, all parts and rules of the message and experience of Islam are valid whenever they are required in the light of changing circumstances in the overall flow of human life and experience. The Islamic rules and systems should always qualify for unlimited combination to fit human needs and circumstances in the light of Islamic goals, values, and principles. Having expressed his viewpoint, Abdul Hamid concludes for the phenomenon, such as the change of qiblah once and for all from the direction of Bayt al-Maqdis to Makkah. ${ }^{90}$ He finally refers to Muṣtafā Abū Zayd that although jurists' and scholars quoted the Companions of the Prophet on the abrogation of this or that verse, they do not quote the Prophet himself in specifying any verse abrogating any other verse. ${ }^{91}$ As a matter of fact, he blames jurists for exhausting a great deal of effort to prove the very existence of abrogation in the Qur'ān.

Nevertheless, in the Islamic intellectual circle the majority of ' $u l a m \bar{a}^{\prime}$ ' agreed to the phenomenon al-naskh rationally and permitted its occurrence legally. They presented a rationale that the activities of God would not be distracted by the goals. According to them, God commanded something at a certain time and abrogated it at a different time. For God knows what is best for His servants. They argue that the text of the Qur'ān and Sunnah clearly proves the existence of al-naskh. ${ }^{92}$

$90 \quad$ Ibid.

91 Ibid.

92 Al-Qur'ān (16:101) and (2:106). 
Jurnal Fiqh: No. 3 (2006)

\section{AL-NASKH AND AL-TAKHṢĪṢ}

A certain amount of confusion has also arisen between alnaskh and al-takhșis due to the conceptual differences between the Hanafi's and the majority of 'ulama $\bar{a}$ ' regarding al-naskh in that they tend to view al-naskh differently from one another. It has also been argued that the change in the meaning of the term naskh in different phase of the development of the phenomenon is responsible for a good deal of confusion. It is observed that some Companions and the early authorities had used the word in the sense of exception, particularizing the meaning (al-takhșiss) and the clarification of a previous verse. It is also claimed that when they stated that a certain verse was al-nassikh for another, they intended thereby that the verse explained and removed the misconception that could arise from a certain passage by comparing it with earlier related one. They did not mean that the latter revelation has totally abrogated and rendered out of force the former one. These different meanings of this word were, however, confused in the later ages and no distinction was drawn between them. ${ }^{93}$

It is quite evident that some Qur'ānic pronunciations are general while others explain and fix their meaning. This is the meaning of the saying that the Qur'ân explains itself. These explanatory verses seem to have been called al$n \bar{a} s i k h$, if the reports are genuine, in the early days. As already stated, al-naskh is basically confined to the Qur'ân and Sunnah and could be only affected by the explicit ruling of divine revelation. Al-Takhșis on the other hand could also occur by means of rationality and circumstantial evidence. Al-Naskh in other words can only occur by shar " (divine injunction) whereas al-takhșiș can occur by rationality ('aql), custom ('urf) and other rational proofs. It would follow from this that al-takhșiș (i.e. specifying or

93 Kamāli, Islamic Jurisprudence, p. 161. 
qualifying a general text) is possible by means of speculative evidence such as qiy $\bar{a}$ s and solitary ( $\bar{a} h \bar{a} d)$ hadith. But in the case of al-naskh, a definitive ruling of the Qur'ān or Sunnah is required to establish an abrogation.

As stated, in al-naskh it is essential that the one that abrogates (al-nāsikh) is later in time than ruling that it seems to abrogate. There can be no al-naskh if this order is not reversed, nor even when the two rulings are known has been simultaneous, but this is not a requirement to altakhșiș. Lastly, al-naskh does not apply to factual reports. Thus, a new report may be specified or qualified but it cannot be abrogated. The closest concept to abrogating in reports is that they can be denied. ${ }^{94}$

The proponents of al-naskh use Ibn 'Abbās statement that the verse 2:183 is not abrogated, but it is meant for old men and women who have no strength to fast, so they should feed one poor person for each day of fasting. According to them it is quite clear that the verse 2:184 does not abrogate the rule of fasting from the verse 2:183 but explains that in a specified case, that of feeble old people, there is a way of making up for the loss of fast. In the same way, they argue that the verse concerning intoxicating drinks can be understood as specifications rather than abrogation.

It has been argued by those who are not in favour of abrogation but in favour of al-takhsis that al-naskh and altakhșis differ from one another and in that there is no real conflict in takhșis. The two takhșis that are the general text and the specific text, in effect, complement one another. This is not, however, the case in al-naskh in which it is necessary that two rulings are genuinely in conflict and that they could not co-exist. Another difference between alnaskh and al-takhșis is that al-naskh can occur in respect of

${ }^{94}$ Ibid., See also: al-Ihkām Fì Ușūl al-Ahkām by al-'Āmidì. 
Jurnal Fiqh: No. 3 (2006)

either a general or a specific ruling whereas al-takhsisis can be as definition, or occur in respect of a general ruling only. ${ }^{95}$

\section{ORIENTALISTS' VIEWS}

The issue of abrogation has given rise to great interest and excitement among several Orientalists apart from Muslim scholars. According to Orientlalists the subject of abrogation is unacceptable and a few of them even imagine that God has changed His mind and thereof inconsistency is reflected. Many passages in the Qur'ān are described as contradictory and inconsistent. Their views on abrogation to be a cancellation of the older verse and its replacement by a contradictory one are blasphemous assertion that God changes His mind. This is categorically untrue, as the foregoing pages shed sufficient light in refuting their contention. Gruenebaun argues that the karonic concept seems somewhat more mechanical. ${ }^{96}$ However he is in agreement with the theory of naskh which according to him proves that the Qur'ān was subjected to alteration in its initial stages. ${ }^{97}$ Noledeke considered the theory of naskh has originated from the Christian idea. He says that one revelation is abrogated by another is such an unprecedented notion that it could not very well have been invented by Muhammad. ${ }^{98}$

\section{CONCLUSION}

The above analytical study reveals that the phenomenon of al-naskh applies to the Qur'ān and Sunnah. However, it is very clear that the application of al-naskh to the Qur'àn and

95 Ibid.

96 Grunnebaun (1965), G.E. von. Islam, London, p. 85.

97 Alfred Guillaume (1962), Islam, Edinburgh: n.p, p. 189.

98 Theodor Noledeke Geschiche de Qorans (Hildshein: n.p. 1961), p. 52. 
Sunnah is confined to the lifetime of the Prophet only. There is no al-naskh after the death of the Prophet. But the occurrence of al-naskh has been widely discussed by the 'ulam $\bar{a}$ ' and scholars throughout Islamic history. Many arguments were and are being made, as a result, the majority of scholars have accepted the occurrence of alnaskh and a minority has denied it. The present research makes it possible to conclude that al-naskh had occurred in the Qur'ān. There are many proofs that one can understand its possibility. As God revealed the Qur'ān to the Prophet gradually within twenty-three years, it is possible for the occurrence of al-naskh in which the latter revelation abrogates the former.

Since God knew that man cannot bear and accept the rulings simultaneously, He provided convenience by sending down His revelation step by step. Thus He gave them time to practice the rulings given by Him. In this way al-naskh occurred according to their time and situation by giving or adding new rules and abrogating the previous one. As a result of this method, people gradually accepted the rules without any practical difficulty in their daily life.

However, those who disagree with the occurrence of alnaskh do not reject the idea of the gradual revelation of the Qur'ān, but they say that it is not ideal to call the previous ruling, which is not practiced after the new rule, as an "abrogated one". So according to them, the previous rulings also must be given equal position in the Qur'ann and therefore considered as part of the revelation forever without referring to them by any special name such as abrogation. In addition, it is suggested that when the phenomenon of abrogation is advocated in the Qur'ān it will open the door for criticism. However, in short, none among them denied the gradual revelation or changing of the rulings from time to time in the Qur'ān. So it can be concluded that while they all agree on the change of the 
Jurnal Fiqh: No. 3 (2006)

rulings in the Qur'ān, they will have different approaches in calling those rulings either as al-naskh or al-takhșiș.

Last, but not least, as a result of this current study it is hereby strongly recommended that in the existence of misunderstandings and misconceptions over the issue, it is important to re-discuss the phenomenon of al-naskh and reach an ijma ' between the 'ulam $\bar{a}^{\prime}$, scholars, jurists, thinkers, exegetes, and social scientists to avoid further complications and controversies in the academic and educational institutions of higher learning where there is an existence of division on this basis which lead to unpleasant results. After all one of the principles of Islamic law is the ijm $\bar{a}$ ' of the ummah is binding on the rest. Therefore there is a need for an $i j m \bar{a}$ 'on this issue. 